\title{
Megafaunal extinctions and their consequences in the tropical Indo-Pacific
}

\author{
Richard T. Corlett \\ Department of Biological Sciences, National University of Singapore, Singapore \\ corlett@nus.edu.sg
}

\section{Introduction}

The global Quaternary Megafauna Extinction (QME) event eliminated two-thirds of all mammal genera and half (c. 178) of all species of body mass $>44 \mathrm{~kg}$, with most well-dated extinctions occurring between c. 50,000 and 3000 years ago (Barnosky 2008). The QME differed from other extinction events in the fossil record by the absence of replacements, the fact that similar episodes occurred in widely separated sites at different times, and the fact that the timing can often be loosely linked with the arrival of modern humans. The causes and consequences of this event have been debated at length in the literature for Australia, Madagascar, northern Eurasia, and both North and South America, with Africa often used as a 'control' in comparisons (Koch and Barnosky 2006; Barnosky 2008; Johnson 2009), but tropical Asia, Wallacea (the Indonesian Islands separated by deep water from the Asian and Australian continental shelves) and New Guinea have generally been omitted from these debates. This partly reflects uncertainties in the fossil and archaeological records of the region - in particular, about the timing of large vertebrate extinctions in relation to the arrival first of early Homo and then of modern humans (Bird et al. 2004; Louys et al. 2007; Corlett 2009a). However, the Asian mainland, all large islands and many smaller ones supported more large vertebrate species and much more large vertebrate biomass in the Pleistocene than they do now (Long et al. 2002; Louys et al. 2007; Louys 2008) and an ongoing extinction episode threatens all the survivors (Corlett 2007). Here, I ask what has been lost, when and why, and what the ecological consequences have been.

\section{Who was where when?}

The earliest human remains in the region are assigned to Homo erectus. Most skeletal remains are from Java, 1.0-1.8 million years ago, but the earliest securely dated stone tools are from the island of Flores (Morwood et al. 1998) and South China (Hou et al. 2000), only 800,000 years ago. Most of the faunal remains associated with $H$. erectus finds suggest 
open woodland or savanna and it is not clear whether the species could live in closed forest. Other unknowns are its ability to manipulate fire and to make voluntary sea crossings, such as those needed to reach Flores. Later Asian populations of $H$. erectus appear to have diverged increasingly from their African ancestors, and mainland East Asia was occupied between about 500,000 and 70,000 years ago by hominids who may have represented evolutionary developments from local $H$. erectus populations and/or archaic forms of $H$. sapiens and/or additional Homo species (Bacon et al. 2006; Louys et al. 2007). A remarkable dwarf hominin, H. floresiensis, inhabited a limestone cave on Flores from 95 ka to $16.6 \mathrm{ka}$ (Moore et al. 2009).

There is no clear archaeological evidence for anatomically and culturally modern humans in Eurasia before about 45,000-50,000 years ago. This fits with the growing amount of archaeological, genetic, pollen and charcoal evidence in support of a single dispersal event that brought modern humans from Africa, where they had emerged 150,000-200,000 years ago, along the coastlines of South and Southeast Asia, to New Guinea and Australia, within a period of a few thousand years (Mellars 2006; Pope and Terrell 2008). This 'coastal express train' model of modern human dispersal assumes that the pioneer populations lived initially on coastal resources, moving on as those resources became depleted, and only later moved inland.

\section{When was what where?}

There is no clear functional justification for a $44 \mathrm{~kg}$ cut-off in the definition of megafauna (Martin and Klein 1984; Hansen and Galetti 2009), but this limit has been widely used in the literature and is followed here for convenience. Owen-Smith's $1000 \mathrm{~kg}$ minimum has much stronger functional justification (Owen-Smith 1988), but includes few Pleistocene taxa in the region between tropical China and New Guinea covered here. Holocene extinctions of smaller $(<44 \mathrm{~kg})$ mammals (only island rats and bats in this region) are covered by Turvey (2009b). The only known terrestrial megafaunal or near-megafaunal species on the tropical islands east of New Guinea were the land turtles, terrestrial crocodiles and giant flightless birds that persisted into the Holocene on New Caledonia and Fiji (Turvey 2009a).

It would be interesting to examine the large vertebrate fauna of the region over the full period of hominin occupation, but the problems of interpretation of the fossil record increase rapidly as one goes back in time, so this review is limited to the past million years, with the main focus on the late Pleistocene, from c. $130 \mathrm{ka}$, and the Holocene (Table 1). This summary builds on those by Long et al. (2002), Louys et al. (2007) and Louys (2008), updated where necessary. I have checked the primary sources wherever possible and taken a critical stance when examining the Asian literature, excluding some doubtful records. Scientific names of all taxa are given in Table 1. This table underestimates the regional loss of megafaunal species because late Pleistocene fossils have usually been assigned to the nearest living relative, or to a single extinct taxon, while recent molecular studies have often divided extant taxa (e.g. orangutans, clouded leopards) into geographically separated species. It also gives a very misleading impression of the extent of local megafaunal losses, since many large vertebrates still persist somewhere in the region, despite occupying $<10 \%$ of their maximum Holocene ranges and an even smaller percentage of their maximum Pleistocene ranges. 
Table 1. Terrestrial vertebrates with body mass $>44 \mathrm{~kg}$ recorded from the Indo-Pacific region (tropical China to New Guinea) from the Late Pleistocene to present day, showing the maximum geographical range, most recent time period when the species was extant within the region, and estimated range of body masses. The table underestimates extinctions, since Late Pleistocene fossils have usually been assigned to the nearest living relative or to a single extinct taxon, while recent molecular studies have tended to divide extant taxa into geographically separated species. Almost all extant species occupy $<10 \%$ of their maximum Holocene range and an even smaller percentage of their Pleistocene one (Table 1 continues on page 120)

\begin{tabular}{|c|c|c|c|c|c|}
\hline \multicolumn{2}{|l|}{ Taxon } & Maximum range & Last known extant & Mass (kg) & Common name \\
\hline \multicolumn{6}{|l|}{ SQUAMATA } \\
\hline \multirow[t]{3}{*}{ Varanidae } & Varanus spp. & Wallacean islands & late Pleistocene & ?? & monitor lizards \\
\hline & Varanus komodoensis & Flores, Komodo etc. & extant & $<165$ & Komodo dragon \\
\hline & V. salvadorii & New Guinea & extant & $<50$ ? & $\begin{array}{l}\text { crocodile } \\
\text { monitor }\end{array}$ \\
\hline \multirow[t]{3}{*}{ Pythonidae } & Morelia spp. & New Guinea & extant & ?? & pythons \\
\hline & Python molurus & S. China-Sulawesi & extant & $<140$ & Burmese python \\
\hline & P. reticulatus & SE Asia-Wallacea & extant & $<160$ & $\begin{array}{l}\text { reticulated } \\
\text { python }\end{array}$ \\
\hline \multicolumn{6}{|l|}{ TESTUDINATA } \\
\hline Testudinidae & Geochelone spp. & Wallacean islands & Pleistocene & ?? & giant tortoises \\
\hline \multicolumn{6}{|c|}{ CASUARIIFORMES } \\
\hline \multirow[t]{2}{*}{ Casuariidae } & Casuarius casuarius & New Guinea & extant & $30-60$ & $\begin{array}{l}\text { southern } \\
\text { cassowary }\end{array}$ \\
\hline & C. unappendiculatus & New Guinea & extant & $40-60$ & $\begin{array}{l}\text { northern } \\
\text { cassowary }\end{array}$ \\
\hline \multicolumn{6}{|c|}{ DIPROTODONTIA } \\
\hline \multirow[t]{3}{*}{ Diprotodontidae } & Hulitherium & New Guinea & after $40,000 \mathrm{BP}$ & 150 & \\
\hline & Maokopia & New Guinea & after $40,000 \mathrm{BP}$ & 100 & \\
\hline & Zygomaturus & New Guinea & after $40,000 \mathrm{BP}$ & 300 & \\
\hline Macropodidae & Protemnodon spp. & New Guinea & after $40,000 \mathrm{BP}$ & $45-100$ & kangaroo \\
\hline \multicolumn{6}{|c|}{ PROBOSCIDEA } \\
\hline \multirow[t]{4}{*}{ Elephantidae } & Elephas spp. & Sulawesi, Luzon & Pleistocene & ?? & dwarf elephants \\
\hline & Elephas maximus & China to Java & extant & $\begin{array}{r}2500- \\
4000 \\
\end{array}$ & Asian elephant \\
\hline & $\begin{array}{l}\text { Palaeoloxodon } \\
\text { naumanni }\end{array}$ & China, Vietnam & late Pleistocene & ?? & $\begin{array}{l}\text { straight-tusked } \\
\text { elephant }\end{array}$ \\
\hline & Stegodon spp. & China to Timor & mid P. to Holocene & $\begin{array}{r}300- \\
3000 ?\end{array}$ & stegodons \\
\hline \multicolumn{6}{|l|}{ PRIMATES } \\
\hline \multirow[t]{3}{*}{ Hominidae } & Pongo spp. & China to Java & late P. to Holocene & $>50$ & orangutans \\
\hline & P. abelii & Sumatra & extant & $40-90$ & $\begin{array}{l}\text { Sumatran } \\
\text { orangutan }\end{array}$ \\
\hline & P. pygmaeus & Borneo & extant & $30-90$ & $\begin{array}{l}\text { Bornean } \\
\text { orangutan }\end{array}$ \\
\hline \multicolumn{6}{|l|}{ PHOLIDOTA } \\
\hline Manidae & Manis sp. & Borneo & $40,000 \mathrm{BP}$ & $50 ?$ & giant pangolin \\
\hline \multicolumn{6}{|l|}{ CARNIVORA } \\
\hline \multirow[t]{2}{*}{ Felidae } & Panthera pardus & China to Java & extant & $30-70$ & leopard \\
\hline & P. tigris & China to Java & extant & $75-250$ & tiger \\
\hline \multirow[t]{2}{*}{ Hyaenidae } & Crocuta crocuta & China to Thailand & extant (Africa) & $45-80$ & spotted hyena \\
\hline & $\begin{array}{l}\text { Pachycrocuta } \\
\text { brevirostris }\end{array}$ & China to Java & late Pleistocene? & $>100$ & giant hyena \\
\hline Ursidae & $\begin{array}{l}\text { Ailuropoda } \\
\text { melanoleuca }\end{array}$ & China to Thailand & extant & $70-115$ & giant panda \\
\hline
\end{tabular}




\begin{tabular}{|c|c|c|c|c|c|}
\hline \multicolumn{2}{|l|}{ Taxon } & \multirow{2}{*}{$\begin{array}{l}\text { Maximum range } \\
\text { China to Java }\end{array}$} & \multirow{2}{*}{$\begin{array}{l}\text { Last known extant } \\
\text { extant }\end{array}$} & \multirow{2}{*}{\begin{tabular}{r|} 
Mass $(\mathbf{k g})$ \\
$25-65$
\end{tabular}} & \multirow{2}{*}{$\begin{array}{l}\text { Common name } \\
\text { sun bear }\end{array}$} \\
\hline & Helarctos malayanus & & & & \\
\hline & Ursus thibetanus & China to Thailand & extant & $50-180$ & $\begin{array}{l}\text { Asiatic black } \\
\text { bear }\end{array}$ \\
\hline \multicolumn{6}{|c|}{ PERISSODACTYLA } \\
\hline \multirow[t]{5}{*}{ Rhinocerotidae } & $\begin{array}{l}\text { Dicerorhinus } \\
\text { sumatrensis }\end{array}$ & China to Borneo & extant & $500-1000$ & $\begin{array}{l}\text { Sumatran } \\
\text { rhinoceros }\end{array}$ \\
\hline & $\begin{array}{l}\text { Rhinoceros } \\
\text { philippinensis }\end{array}$ & Luzon & Pleistocene & $<800$ & \\
\hline & $R$. sinensis & China, Vietnam & after $40,000 \mathrm{BP}$ & $>1000$ & \\
\hline & R. sondaicus & China to Java & extant & $\begin{array}{r}1500- \\
2000\end{array}$ & Javan rhinoceros \\
\hline & R. unicornis & China to Java & extant (S. Asia) & $\begin{array}{r}1600- \\
3000\end{array}$ & $\begin{array}{l}\text { Indian } \\
\text { rhinoceros }\end{array}$ \\
\hline \multirow[t]{2}{*}{ Tapiridae } & $\begin{array}{l}\text { Megatapirus } \\
\text { augustus }\end{array}$ & China to Laos & Holocene & $>500$ & giant tapir \\
\hline & Tapirus indicus & China to Java & extant & $200-400$ & Malayan tapir \\
\hline \multicolumn{6}{|c|}{ ARTIODACTLYA } \\
\hline \multirow[t]{2}{*}{ Suidae } & Babyrousa spp. & Sulawesi \& islands & extant & $50-100$ & babirusa \\
\hline & Sus spp. & China to Sulawesi & extant & $10-150$ & pigs \\
\hline \multirow[t]{10}{*}{ Cervidae } & Axis calamianensis & Calamian Islands & extant & $30-90$ & Calamian deer \\
\hline & A. kublii & Bawean & extant & $36-50$ & Bawean deer \\
\hline & A.porcinus & China to Thailand & extant & $36-50$ & hog deer \\
\hline & $\begin{array}{l}\text { Elaphodus } \\
\text { davidianus }\end{array}$ & China & recent & $150-200$ & $\begin{array}{l}\text { Père David's } \\
\text { deer }\end{array}$ \\
\hline & Cervus eldii & China to Thailand & extant & $<150$ & Eld's deer \\
\hline & $\begin{array}{l}\text { Rucervus } \\
\text { schomburgki }\end{array}$ & Thailand & 1932 & $100-120$ & $\begin{array}{l}\text { Schomburgk's } \\
\text { deer }\end{array}$ \\
\hline & Rusa alfredi & Visayan Islands & extant & $25-80$ & $\begin{array}{l}\text { Visayan spotted } \\
\text { deer }\end{array}$ \\
\hline & R. marianna & Philippines & extant & $40-60$ & Philippine deer \\
\hline & R. timorensis & Java \&Bali & extant & $75-160$ & Javan rusa \\
\hline & R. unicolor & China to Borneo & extant & $100-300$ & sambar \\
\hline \multirow[t]{12}{*}{ Bovidae } & Bos frontalis & China to Malaysia & extant & $700-1500$ & gaur \\
\hline & B. javanicus & China to Java & extant & $600-800$ & banteng \\
\hline & B. sauveli & $\begin{array}{l}\text { Vietnam to } \\
\text { Thailand }\end{array}$ & recent & $<900$ & kouprey \\
\hline & Bubalus spp. & Philippines & late Pleistocene & & \\
\hline & B. arnee & Myanmar-Java & extant & $800-1200$ & $\begin{array}{l}\text { wild water } \\
\text { buffalo }\end{array}$ \\
\hline & B. depressicornis & Sulawesi & extant & $150-300$ & lowland anoa \\
\hline & B. mephistopheles & China & mid Holocene & $<1000$ & $\begin{array}{l}\text { short-horned } \\
\text { water buffalo }\end{array}$ \\
\hline & B. mindorensis & Mindoro & extant & $180-300$ & tamaraw \\
\hline & B. quarlesi & Sulawesi & extant & $150-300$ & mountain anoa \\
\hline & $\begin{array}{l}\text { Pseudoryx } \\
\text { nghetinhensis }\end{array}$ & Laos, Vietnam & extant & 100 & saola \\
\hline & $\begin{array}{l}\text { Capricornis } \\
\text { milneedwardsii }\end{array}$ & China to Thailand & extant & $50-140$ & Chinese serow \\
\hline & C. sumatraensis & Thailand to Java & extant & $50-140$ & Sumatran serow \\
\hline
\end{tabular}




\section{New Guinea}

The largest extant varanid in New Guinea (Varanus salvadorii) and the largest pythons (Morelia spp.) may occasionally reach megafaunal size, and New Guinea supports two megafaunal cassowary species (Wright 2005). The late Pleistocene fauna of the New Guinea highlands also included several now-extinct marsupials of megafaunal size, including large browsing kangaroos (Protemnodon spp.) and diprotodontids (Hulitherium, Maokopia, Zygomaturus) (Long et al. 2002; Fairbairn et al. 2006).

\section{Wallacea (excluding Sulawesi)}

Potentially megafaunal reptiles on the oceanic islands of Wallacea (Figure 1) included varanids, pythons and giant tortoises. Megafaunal varanids (Varanus komodoensis) are now confined to Komodo, western Flores and a couple of nearby islands, and all giant tortoises are extinct, but pythons (Python reticulatus) occur on most islands, apparently as natives. However, although this species reaches megafaunal sizes on the mainland and continental islands, with a 6-7 m snake weighing $>50 \mathrm{~kg}$ (Fredriksson 2005), at least some of the Wallacean forms are dwarfed (Auliya et al. 2002). Proboscids were apparently the only mammals able to swim the sea straits east of Bali. Pleistocene fossil dwarf stegodons are known from several localities on Timor, along with a giant tortoise and a large varanid, but all these seem to have vanished before the first evidence for modern humans at 40,000 BP (O'Connor 2007). Fossil dwarf stegodons of uncertain age have also been reported from Sumba (Sartono 1979) and from the tiny island of Sangihe, between Sulawesi and Mindanao (van den Bergh et al. 1996). On Flores, a dwarf (c. $300 \mathrm{~kg}$ ) stegodon species from $900 \mathrm{ka}$ was replaced by $850 \mathrm{ka}$ by a larger species, which in turn became dwarfed, before disappearing c. $12 \mathrm{ka}$ (van den Bergh et al. 2008). The Komodo dragon persisted throughout this sequence and is the only extant native megafaunal species, but a giant tortoise was last recorded at $900 \mathrm{ka}$.

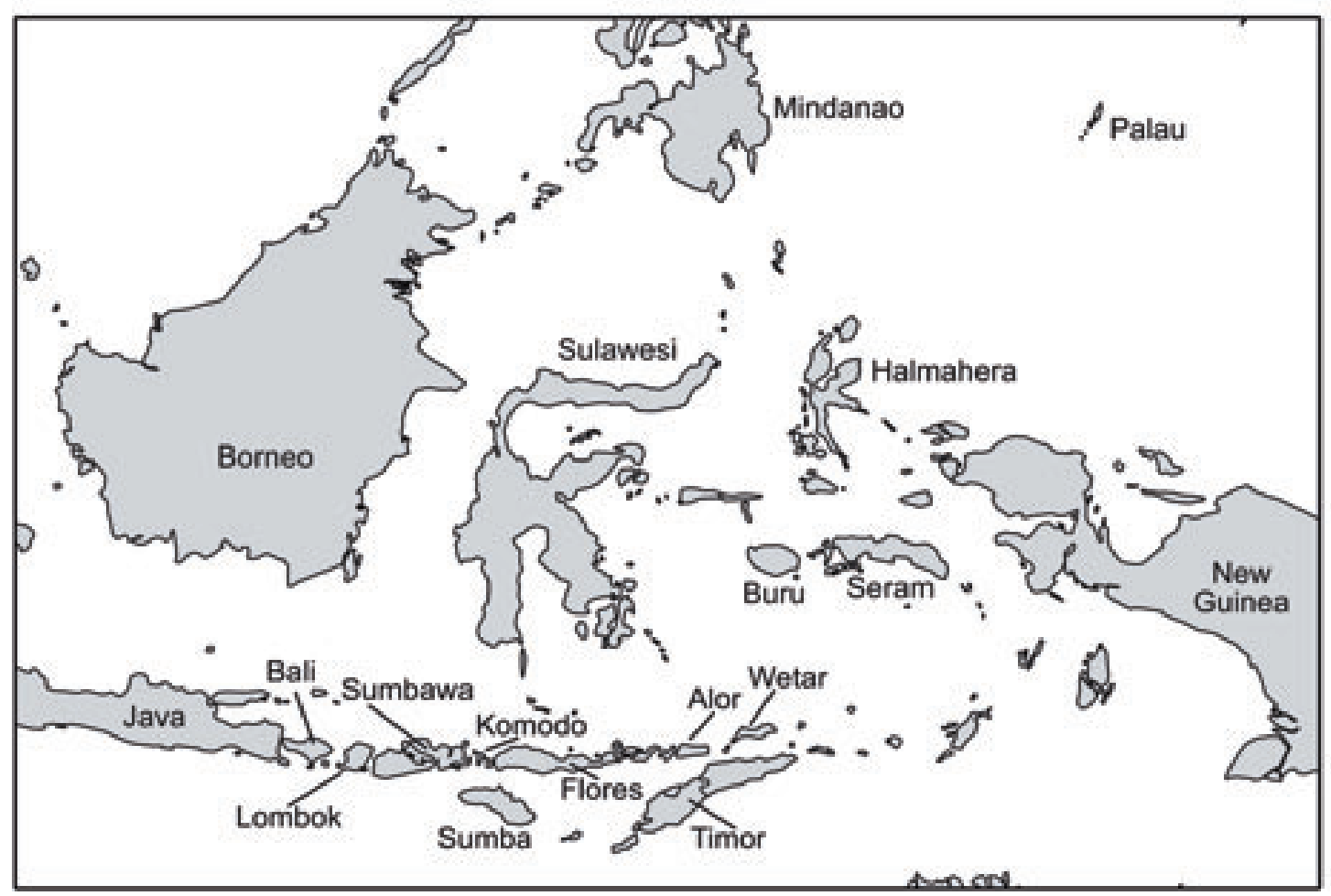

Figure 1. Map of Wallacea and the surrounding region 


\section{Sulawesi}

At the Last Glacial Maximum, the Makassar Straits separating Sulawesi from Borneo were only $45 \mathrm{~km}$ wide at the narrowest point. The Pleistocene fossil fauna had a number of extinct genera, including giant tortoises, stegodonts, elephants and a large suid, Celebochoerus heekereni, but it is not clear whether any of these survived into the late Pleistocene (van den Bergh et al. 2001). The extant megafauna includes the babirusas, a pig (Sus celebensis), two species of anoa, and the reticulated python.

\section{Philippines}

At Pleistocene low sea levels, most of the land area of the Philippines was in six major islands, separated by narrow straits. Only Palawan and the adjacent small islands may ever have been connected to Borneo and it is not clear whether or when this last happened. Palawan supports a subset of the Bornean fauna, including species not found elsewhere in the Philippines, but it also has several endemic species and subspecies. Tigers were present until at least the late Pleistocene and a deer became extinct in the mid Holocene (Piper et al. 2008). The extant Calamian deer is endemic to islands in the Palawan Group. Excluding the Palawan Group, the extant megafauna of the Philippines consists of endemic pigs, deer and the tamaraw, plus the widespread reticulated python (which is possibly a human introduction on some islands). There are also fossils of extinct Bubalus species on Luzon and Cebu, suggesting this genus may once have been present throughout the Philippines (Croft et al. 2006). There are poorly dated Pleistocene fossils of stegodonts on Luzon and Mindanao, and fossils of both elephants and rhinoceroses on Luzon (Bautista 1991; van den Bergh et al. 1996).

\section{Java}

The megafauna coexisting with $H$. erectus on middle Pleistocene Java included stegodons, hippopotamuses and hyenas (Louys et al. 2007), but Java appears to have had a fully modern fauna by $120 \mathrm{ka}$ (Westaway et al. 2007), and - assuming that the fossils are correctly attributed to modern species - no species recorded since then has become globally extinct. The late Pleistocene megafauna consisted of the Asian elephant, orangutan, tiger, leopard, sun bear, Malayan tapir, Javan rhinoceros, Javan rusa, banteng, wild water buffalo, Sumatran serow, Javan warty pig, Eurasian wild pig and two species of python. The elephant, orangutan, tiger, sun bear, tapir and serow disappeared in prehistoric to early colonial times and the Javan rhinoceros has been reduced to a single population of 60 individuals. An extant endemic species of deer occurs on Bawean Island, $150 \mathrm{~km}$ north of Java.

\section{Borneo and Sumatra}

The only fossil evidence of proboscideans from the huge continental island of Borneo is teeth of uncertain provenance (Cranbrook and Piper 2007), while the current population of wild elephants in the northeast seems best explained by the traditional story of introduction from Java via Sulu (Cranbrook et al. 2008). A giant (probably megafaunal) species of pangolin is known from parts of a single individual dated at c. 40,000 ka (Piper et al. 2007a). The known Holocene megafauna included three taxa: Javan rhinoceros (Cranbrook and Piper 2007), Malayan tapir (Cranbrook and Piper 2009) and tiger (Piper et al. 2007b), which became extinct before - possibly just before - modern times. The surviving megafauna consists of the Bornean orangutan, sun bear, Sumatran rhinoceros, bearded pig, sambar deer, banteng and reticulated python. Sumatra has a poorer fossil record than Borneo and the only known megafaunal extinction to occur between the late Pleistocene and historical times is the leopard (Louys et al. 2007), while the Javan rhinoceros is a recent extinction. In contrast to Borneo, elephants, tigers and tapirs still survive, along with the Sumatran orangutan, sun bear, 
Sumatran rhinoceros, bearded pig, sambar deer and reticulated python. All but pigs, deer, tapirs and pythons are currently severely threatened by hunting (Corlett 2007).

\section{Continental Southeast Asia and South China}

During the middle Pleistocene, hominins in South China and Vietnam coexisted with a diverse megafauna that included a giant (estimated $540 \mathrm{~kg}$ ) ape, Gigantopithecus, which became extinct around $300 \mathrm{ka}$ (Rink et al. 2008). Some elements of this fauna persisted into the late Pleistocene and several taxa that are now globally extinct survived into the early Holocene. These late survivors include at least one species of stegodon, a giant tapir and the spotted hyena (Louys et al. 2007). Note, however, that these Holocene dates are considered questionable by Turvey (2009a). In the middle to late Pleistocene, orangutans and giant pandas occurred at many sites from southern China to Thailand (Louys et al. 2007; Zhang et al. 2007). The Malayan tapir is also recorded from late Pleistocene sites in China.

Megafaunal range declines and extinctions have been better documented in China than elsewhere, with more archaeological sites and longer historical records. Stegodons, Malayan and giant tapirs, hyenas and orangutans disappeared before the start of historical records. The short-horned water buffalo (Bubalus mephistopheles) became globally extinct in early historical times (Yang et al. 2008). The decline of the giant pandas started in the late Pleistocene and accelerated in historical times (Loucks et al. 2001; Zhang et al. 2007), while the retreat of the elephants and rhinoceroses (one to two species) has occurred largely over the past 3000 years, with a progressive withdrawal of the northern boundaries of their distributions in the face of growing population pressures (Corlett 2007). Historical data suggest a threshold value of about four people per square kilometres for rhinos, and 20 people for elephants, above which they did not persist (Liu 1998). Rhinoceroses became extinct within the past 30 years in China and elephants have been reduced to tiny populations near the southwestern borders. The declines started later in continental Southeast Asia, but only a tiny population of Javan rhinoceroses and a few scattered Sumatran rhinoceroses still survive, and the Asian elephant occupies a fraction of its 19 th century range (Corlett 2007). Tigers have been eliminated from southern China and are in rapid decline everywhere else in the region, while leopards and the two Southeast Asian bear species have been eliminated from most of the more accessible parts of their continental ranges.

All tropical Asian bovids are currently threatened by hunting (Corlett 2007) and the kouprey may be extinct. Deer are often considered relatively resilient to hunting, but all species have declined severely in recent decades, including the widespread sambar, and this group includes the only two global extinctions (in the wild) in the region within the past 150 years. Schomburgk's deer inhabited marshy grasslands in the central plains of Thailand, but has been extinct since 1938, while further north, Père David's deer was eliminated from riverine marshland in the lower reaches of the Yangtze River more than a century ago and recently has been reintroduced. Eld's deer, which occurs in open forests, has also had its range drastically reduced over the past century. Pigs are the 'last large mammal standing' in many areas, but pig populations have shown massive recent declines as a result of overhunting.

\section{Why?}

Many early and middle Pleistocene extinctions appear to represent a natural process of species turnover, although there are some conspicuous exceptions, such as the giant tortoises and hippopotamuses (Louys et al. 2007), but by the late Pleistocene, extinctions without replacement predominate, matching the pattern seen in the Quaternary Megafauna Extinction event elsewhere on the planet (Barnosky 2008). Unlike other well-documented examples of the QME, however, there is no evidence to suggest a single, sharp extinction event, and no 
obvious peak with the presumed arrival of modern humans around 50,000 years ago. Instead, there has been a steady trickle of regional then global extinctions, mostly within the past 40,000 years and many within the Holocene. The inadequacies of the fossil record and its dating have inevitably blurred the true history of megafaunal extinctions in the region, but surely not enough to account for the broad spread of apparent extinction dates.

The megafaunal losses described above have been attributed by different authors to various combinations of direct (i.e. hunting) and/or indirect (habitat modification) human impacts and natural environmental change. If the region had been completely uninhabited for the past million years, it would be possible to build a plausible case for attributing most of the prerecent losses to environmental change, in particular the development of dense, closed-canopy forest over all but the driest parts of the region at the start of the Holocene. Ground-dwelling herbivores are denied access to the majority of the leaf production in a closed-canopy forest, since this takes place in the canopy. A decline in the density of terrestrial herbivores in turn threatens the largest carnivore, the tiger, which does not have access to arboreal prey, as well as putting pressure on the leopard. The extinction of the giant pangolin may also reflect the loss of open habitats that have a high density of accessible ant and termite nests at the start of the Holocene (Medway 1972). A problem with such environmental explanations, however, is they require that late Pleistocene environments and/or the transition to the Holocene were uniquely difficult periods for megafaunal species. Each glacial and interglacial period is different, but there is no independent evidence that the past 100,000 years has been significantly more difficult for large vertebrates than previous glacial cycles (Barnosky et al. 2004). Volcanoes have also been invoked as agents of extinction, particularly on Flores, where faunal turnovers at $900 \mathrm{ka}$ and $12 \mathrm{ka}$ both coincided with volcanic eruptions. However, the largest eruption on Earth during the late Pleistocene, that of Toba on Sumatra 74,000 years ago, did not coincide with any known extinctions in the region (Louys 2007).

Environmental explanations that may be plausible in the absence of people become less plausible in their presence. The capabilities of Homo erectus are largely unknown, but it is hard to imagine a large, relatively intelligent, omnivorous, social primate coexisting for long with something as vulnerable as a giant tortoise. Giant tortoises are known from Sulawesi, Flores and other islands in the early to middle Pleistocene, and disappeared on Flores around the time hominins, presumably $H$. erectus, arrived (van den Bergh et al. 2001). H. erectus was associated at various times and places with other large vertebrates that no longer survive in the region. A dwarf stegodon was lost from Flores at the same time as the giant tortoise, and the bones of its dwarfed successor are associated with those of $H$. floresiensis in late Pleistocene cave deposits (van den Bergh et al. 2008). Extinct megafauna, including elephants, stegodons and rhinoceroses, are associated with early stone tools in the Philippines (Bautista 1991). Human fossils and/or stone tools from middle and late Pleistocene cave sites in southern China and Indochina are also often associated with the remains of stegodons and the giant tapir (Ciochon and Olsen 1991; Bekken et al. 2004; Schepartz et al. 2005). Early Homo was also associated at some sites with Gigantopithecus (Ciochon et al. 1996; Harrison et al. 2002). These associations suggest some form of interaction, but there is no direct evidence for hunting, and scavenging is equally plausible in most cases.

Although the evidence for an impact of $H$. erectus on megafaunal survival is weak, it is surely significant that the clearest association between human arrival and megafaunal loss is in the New Guinea highlands (Fairbairn et al. 2006; Field et al. 2008), which H. erectus did not reach. The lack of a single, clear extinction event in tropical Asia could thus simply reflect the complex chronology of hominin habitation. In contrast to most other regions of the world outside Africa, where naive megafauna were faced by expanding populations of technologically sophisticated, habitat-generalist, modern humans, tropical Asia’s fauna had a relatively gradual introduction to the perils of humanity. If, as seems likely, H. erectus avoided closed-canopy forest and, at least initially, lacked projectile weapons and mastery of fire, impacts may have 
been slow and selective in comparison with those of modern humans, and may have allowed time for some adaptive evolution.

With modern Homo sapiens, there is no need to speculate on its hunting ability, but it is reasonable to question whether human population densities before the second half of the Holocene were high enough to lead to faunal extinctions. The absence of a well-defined massextinction event in tropical Asia in the 60,000-40,000 BP period during which modern humans probably arrived is consistent with the 'coastal express train' model, with coastal populations moving on as they depleted resources, and only later moving inland. The extinction of the giant pangolin soon after the presumed arrival date was attributed above to the loss of open habitats, but a slow-moving, $2 \mathrm{~m}$ long mammal whose only defence was to roll up must also have been exceptionally vulnerable to hunting. A similar argument can be made for the slowmoving, slow-breeding orangutans, which ranged widely over tropical East Asia in the late Pleistocene, from southern China to Java, but were confined to the sparsely populated everwet rainforests of Borneo and Sumatra by historical times (Delgado and van Schaik 2000). The giant panda and the New Guinea megafaunal marsupials may also have been particularly vulnerable to hunters for similar reasons, but there seems to be no obvious pattern to most other pre-recent extinctions.

Many authors have combined the two major hypotheses and argued that a deteriorating environment combined with pressure from hunting or anthropogenic habitat-modification to push species over the edge into extinction. This is in many ways an unsatisfactory compromise, and is hard to test or refute, but it is equally difficult to argue that either factor - drastic changes in climate and vegetation, or the arrival and expansion of successive human species - had no significant impact on megafaunal populations. A predominance of human impacts over environmental change becomes increasingly clear over the past few thousand years and the role of human exploitation in the drastic range reductions shown by all surviving megafaunal species in the past century is undeniable (Corlett 2007).

\section{Consequences}

Whatever the causes of the large reductions in megafaunal diversity and biomass over the past 130,000 years, the consequences are likely to have been, and continue to be, significant. Indeed, if megafaunal impacts were significant, the vegetation and associated fauna of much of the region may now be in a state of long-term relaxation from these impacts (Johnson 2009). Very large herbivores may have kept vegetation in a more open, patchy condition than exists today. More generally, they may have acted as 'ecosystem engineers', modifying the physical environment in a way that affects other species (Pringle 2008). The largest surviving megaherbivores, the forest elephants and rhinoceroses, are browsers, with the strength to push down, break off, or uproot shrubs, saplings and small trees (Corlett 2007). Elephant movements can lead to the creation of extensive networks of trails. Loss of megafaunamaintained open habitats would have impacted shade-intolerant plants and smaller terrestrial herbivores that would have suffered reduced access to plant biomass. Large deer and cattle do less incidental damage to vegetation, but are more selective as browsers and grazers. Plants that have coevolved with these large herbivores may invest in physical or chemical defences that are ineffective against smaller herbivores, and may thus lose out in competition with plants that lack these defences when large browsers are removed (Johnson 2009). Dung piles from large herbivores have multiple impacts, creating patchiness and providing habitat for other species (Campos-Arceiz 2009).

In central Africa, forest elephants at natural densities probably disperse more seeds than any other vertebrate species and disperse them over much larger distances (Blake et al. 2009), but dispersal by megaherbivores has received little attention in tropical Asia. Many ripe, fleshy 
fruits reach the ground uneaten, where many are consumed by large terrestrial herbivores, these herbivores including probably all extant species of pigs, deer, cattle, tapirs, elephants and rhinoceroses (Corlett 1998). The indehiscent pods produced by some legumes are consumed by the same animals. A 'megafaunal syndrome' of very large fleshy fruits $(>10 \mathrm{~cm}$ diameter with numerous small seeds, or 4-10 cm diameter with a few large seeds) dispersed largely by mammals with $>1000 \mathrm{~kg}$ body mass has been identified in Africa and Brazil (Guimaraes et al. 2008), but the distribution of such fruits in the tropical Indo-Pacific has not yet been documented. Asian elephants have been reported to prefer large, yellow, sweet-smelling fruits with large, hard seeds (Kitamura et al. 2007). Some studies suggest that they consume less fruit and fewer species than their African relatives, but fruits from 29 species were recorded by mahouts in Myanmar as eaten by work elephants (Campos-Arceiz et al. 2008a), and potential seed dispersal distances are very large ( $<6 \mathrm{~km}$, Campos-Arceiz et al. 2008b). Rhinoceroses also eat large fruits and can potentially move $>10 \mathrm{~km}$ within plausible gut-passage times (Corlett 2009b). Tapirs have a similar potential.

The $44 \mathrm{~kg}$ cut-off used in this study brings in a wider range of fruit types than the classic megafaunal syndrome described from studies on African elephants. Large deer disperse seeds both by regurgitation of large, hard seeds from fleshy fruits (e.g. Prasad et al. 2006) and by defecation of small ones, with some of the latter swallowed incidentally during consumption of foliage (Myers et al. 2004; Yamashiro and Yamashiro 2006). Pigs and bovids disperse small seeds in the same way as deer, but their role, if any, in dispersing larger seeds is not known. The extinct megafaunal marsupials of New Guinea probably dispersed some seeds in the same way as extant grazing and browsing megaherbivores (Webb 2008), but any role they had in the dispersal of large seeds is probably covered by the extant cassowaries, which still disperse seeds in large fruits $(<6 \mathrm{~cm})$ for long distances (Wright 2005; Bradford et al. 2008). Orangutans are the largest arboreal frugivores and eat fruits of many different types, including the biggest species available. Their ability to move large seeds over long distances $(>1 \mathrm{~km})$ is shared with only a few other large-bodied frugivores (Corlett 2009b).

\section{Megafaunal introductions}

Many megafaunal species have been deliberately introduced by people outside their natural ranges and a proportion of these have established wild populations. These successful invasions provide evidence for the existence of 'empty niches' in communities throughout the region, particularly on islands, although in some cases these niches have been created or expanded recently by human modification of the natural vegetation. Pigs (Sus scrofa, S. celebensis, Larson et al. 2007) and deer (mostly Rusa timorensis) were spread throughout the region during the Holocene. The archaeological record for Flores, for example, shows that the only megafaunal animals at the start of the Holocene were people and Komodo dragons, but that people subsequently introduced first the Sulawesi warty pig (Sus celebensis), c. 7000 years ago, and subsequently the Eurasian pig (S. scrofa) and several smaller mammal species (van den Bergh et al. 2008). The archeological record of south Sulawesi shows that deer (Cervus timorensis) first appeared there about 4000 years ago (Simons and Bulbeck 2004). The elephant population on Borneo is apparently also a recent introduction (Cranbrook et al. 2008).

\section{Megafaunal reintroductions?}

If the extinct megafauna played a unique role in the ecosystems they inhabited, it makes sense to consider their reintroduction or replacement. Where megafaunal species have been lost from an area in recent times, but persist elsewhere, then reintroduction is an option. Indeed, many megafaunal species are likely to be favoured by the leaf and shoot biomass available near 
ground level in disturbed and fragmented habitats. Piper and Cranbrook (2007) propose the reintroduction of the Malayan tapir to the Planted Forest Zone in Sarawak, which consists of 490,000 ha of primary, secondary and industrial plantation forests, while several projects are attempting to re-establish orangutans in areas from which they have been extirpated (Corlett 2009a). With an estimated 16,000 captive elephants in Asia and many of these unwanted as their use in logging declines, the major problem with the Asian elephant is a lack of suitable habitat, rather than a shortage of animals for release (Leimgruber et al. 2008). In contrast, both species of forest rhinoceros are critically endangered and neither has a captive population.

Where the extinction was many tree generations ago, it is likely that the current vegetation represents a new equilibrium in which previously suppressed plant species are more abundant and others less abundant than when the megafauna was present at natural densities (Johnson 2009). While restoring the natural situation may seem a laudable aim, it is also possible that the disruption of fragmented forest communities will simply promote invasive alien species, since these are likely to exert a much greater 'propagule pressure' than any rare native species.

Where the missing taxon is globally extinct, but an ecologically similar relative persists, then the introduction of this as a substitute could be considered. A major problem, however, lies in assessing 'ecological equivalence'. For proboscidians, the Asian elephant is the only Asian survivor of a once diverse group. The fact that some of these other taxa coexisted with Asian elephants in the past suggests that they are not complete equivalents, but how much this matters is hard to determine.

\section{Conclusions}

The relatively small number of global extinctions in the Indo-Pacific megafauna in comparison with the rest of the world masks a catastrophic collapse in local species diversity and biomass since the middle Pleistocene. The evidence from the region is frustratingly incomplete, but I consider it most likely that hominin impacts have been the major factor behind most large vertebrate extinctions and range restrictions in the past 130,000 years and probably some earlier ones. Large vertebrates have evolved in or invaded every accessible land mass on Earth and appear to have been a major component of all vertebrate communities since soon after vertebrates evolved, apart from the period immediately after the K/T extinctions 65 million years ago. For their disappearance during the brief period following the expansion of the genus Homo out of Africa to be a mere coincidence would require much stronger evidence than any that is currently available for uniquely extreme environmental pressures during this time. Any uncertainties about the role of human populations disappear by the mid Holocene, and the devastating human impacts of the past century are well documented.

If an anthropogenic explanation for the megafaunal collapse is accepted as most likely, this then raises the question of why there is no clear evidence of rapid overkill soon after the arrival of humans. I have suggested a two-part explanation for this: that Homo erectus lacked (or, at least, initially lacked) the technical skills and forest adaptations needed to cause rapid population collapse, except in the most vulnerable of non-forest taxa, while H. sapiens spread initially along the coast and invaded the forested interior only gradually and unevenly. Indeed, much of the region had extremely low human population densities into historical times (Corlett 2009a). Although the megafauna is equally absent whether it was wiped out by climate change or by humans, the former would be an interesting palaeoecological phenomenon, while the latter, if true, is a historical tragedy and one which we would reverse if we could. Yet the surviving megafauna is everywhere in retreat and more extinctions are likely (Corlett 2007). Conservation successes in the Indo-Pacific tend to be local and small scale, while the larger-scale efforts needed to save viable populations of the largest species appear to be beyond our current capabilities. Some species, such as tigers, will survive in captivity 
whatever their fate in the wild, but others, including the two critically endangered forest rhinoceroses, lack viable captive populations. More than a billion people live in the region covered by this review and this population will continue to rise until at least 2050 (Corlett 2009a). Conservation problems are many and urgent as a result, but the largest vertebrates deserve special attention.

\section{Acknowledgements}

Geoff Hope was hugely influential in my early career, so he is the first person I need to acknowledge. I have also benefited greatly from discussions with Ahimsa Campos-Arceiz.

\section{References}

Auliya, M., P. Mausfeld, A. Schmitz and W. Boehme 2002. Review of the reticulated python (Python reticulatus Schneider, 1801) with the description of new subspecies from Indonesia. Naturwissenschaften 89:201-213.

Bacon, A.-M., F. Demeter, S. Rousse, V.T. Long, P. Duringer, P.-O. Antoine, N.K. Thuy, B. T. Mai, N. T. M. Huong, Y. Dodo, H. Matsumura, M. Schuster and T. Anezaki 2006. New palaeontological assemblage, sedimentological and chronological data from the Pleistocene Ma U'Oi cave (northern Vietnam). Palaeogeography Palaeoclimatology Palaeoecology 230:280-298.

Barnosky, A.D., P.L. Koch, R.S. Feranec, S.L. Wing and A.B. Shabel. 2004. Assessing the causes of Late Pleistocene extinctions on the continents Science 306:70-75.

Barnosky, A.D. 2008. Megafauna biomass tradeoff as a driver of Quaternary and future extinctions. Proceedings of the National Academy of Sciences of the United States of America 105:11543-11548.

Bautista, A.P. 1991. Recent zooarchaeological researches in the Philippines. Jurnal Arkeologi Malaysia 4:45-58.

Bekken D., L.A. Schepartz, S. Miller-Antonio, H. Yamei and H. Weiwen 2004. Taxonomic abundance at Panxian Dadong, a Middle Pleistocene Cave in South China. Asian Perspectives 43: 333-359

Bird, M.I., G. Hope and D. Taylor 2004. Populating PEP II: The dispersal of humans and agriculture through Austral-Asia and Oceania. Quaternary International 118-119:145-163.

Blake, S., S.L. Deem, E. Mossimbo, F. Maisels and P. Walsh 2009. Forest elephants: tree planters of the Congo. Biotropica 41:459-468.

Bradford, M.G., A.J. Dennis and D.A. Westcott 2008. Diet and dietary preferences of the southern cassowary (Casuarius casuarius) in North Queensland, Australia. Biotropica 40:338-343.

Campos-Arceiz, A. 2009. Shit happens (to be useful)! Use of elephant dung as habitat by amphibians. Biotropica 41:406-407.

Campos-Arceiz, A., T.Z. Lin, W. Htun, S. Takatsuki and P. Leimgruber 2008a. Working with mahouts to explore the diet of work elephants in Myanmar (Burma). Ecological Research 23:1057-1064.

Campos-Arceiz, A., A.R. Larrinaga, U.R. Weerasinghe, S. Takatsuki, J. Pastorini, P. Leimgruber, P. Fernando and L. Santamaria 2008b. Behavior rather than diet mediates seasonal differences in seed dispersal by Asian elephants. Ecology 89:2684-2691.

Ciochon, R. and J.W. Olsen 1991. Paleoanthropological and archaeological discoveries from Lang Trang caves: a new Middle Pleistocene hominid site from northern Vietnam. IndoPacific Prehistory Association Bulletin 10:59-73. 
Ciochon, R., V. T. Long, R. Larick, L. Gonzalez, R. Grun, J. De Vos, C. Yonge, L. Taylor, H. Yoshida and M. Reagan 1996. Dated co-occurrence of Homo erectus and Gigantopithecus from Tham Khuyen Cave, Vietnam. Proceedings of the National Academy of Sciences of the United States of America 93:3016-3020.

Corlett, R.T. 1998. Frugivory and seed dispersal by vertebrates in the oriental (Indomalayan) region. Biological Reviews 73:413-448.

Corlett, R.T. 2007. The impact of hunting on the mammalian fauna of tropical Asian forests. Biotropica 39:292-303.

Corlett, R.T. 2009a. The ecology of tropical East Asia. Oxford: Oxford University Press.

Corlett, R.T. 2009b. Seed dispersal distances and plant migration potential in tropical East Asia. Biotropica 41:592-598.

Cranbrook, E.O., J. Payne and C.M.U. Leh 2008. Origin of the elephants Elephas maximus L. of Borneo. Sarawak Museum Journal 63(84):95-125.

Cranbrook, E.O. and P.J. Piper. 2007. The Javan rhinoceros Rhinoceros sondaicus in Borneo. Raffles Bulletin of Zoology 55:217-220.

Cranbrook, E.O. and P.J. Piper 2009. Borneo records of Malay tapir, Tapirusindicus Desmarest: a zooarchaeological and historical review. International Journal of Osteoarchaeology 19:491-507

Croft, D.A., L.R. Heaney, J.J. Flynn and A.P. Bautista 2006. Fossil remains of a new, diminutive Bubalus (Artiodactyla : Bovidae : Bovini) from Cebu Island, Philippines. Journal of Mammalogy 87:1037-1051.

Delgado, R.A., Jr. and C.P. van Schaik 2000. The behavioral ecology and conservation of the orangutan (Pongo pygmaeus): A tale of two islands. Evolutionary Anthropology 9:201-218.

Fairbairn, A.S., G.S. Hope and G.R. Summerhayes 2006. Pleistocene occupation of New Guinea’s highland and subalpine environments. World Archaeology 38:371-386.

Field, J., M. Fillios and S. Wroe 2008. Chronological overlap between humans and megafauna in Sahul (Pleistocene Australia-New Guinea): A review of the evidence. Earth Science Reviews 89:97-115.

Fredriksson, G.M. 2005. Predation on sun bears by reticulated python in East Kalimantan, Indonesian Borneo. Raffles Bulletin of Zoology 53:165-168.

Guimaraes, P.R., Jr., M. Galetti and P. Jordano 2008. Seed dispersal anachronisms: rethinking the fruits extinct megafauna ate. PLoS One 3: Article No. e1745.

Hansen, D.M. and M. Galetti 2009. The forgotten megafauna. Science 324:42-43.

Harrison, T., J. Xueping and D. Su 2002. On the systematic status of the late Neogene hominoids from Yunnan Province, China. Journal of Human Evolution 43:207-227.

Hou, Y.M., R. Potts and B.Y. Yuan 2000. Mid-Pleistocene Acheulean-like stone technology of the Bose basin, South China. Science 287:1622-1626.

IUCN. 2008. 2008 IUCN Red List of threatened species. United Kingdom: International Union for Conservation of Nature and Natural Resources.

Johnson, A., R. Bino and P. Igag 2004. A preliminary evaluation of the sustainability of cassowary (Aves: Casuariidae) capture and trade in Papua New Guinea. Animal Conservation 7:129-137.

Johnson, C.N. 2009. Ecological consequences of Late Quaternary extinctions of megafauna. Proceedings of the Royal Society B 276: 2509-2519.

Kitamura, S., T. Yumoto, P. Poonswad and P. Wohandee 2007. Frugivory and seed dispersal by Asian elephants, Elephas maximus, in a moist evergreen forest of Thailand. Journal of Tropical Ecology 23:373-376.

Koch, P.L. and A.D. Barnosky 2006. Late Quaternary extinctions: State of the debate. Annual Review of Ecology, Evolution and Systematics 37: 215-250 
Larson, G., T. Cucchi, M. Fujita et al. 2007. Phylogeny and ancient DNA of Sus provides insights into neolithic expansion in island southeast Asia and Oceania. Proceedings of the National Academy of Sciences of the United States of America 104:4834-4839.

Leimgruber, P., B. Senior, Uga, M. Aung, M.A. Songer, T. Mueller, C. Wemmer and J.D. Ballou 2008. Modeling population viability of captive elephants in Myanmar (Burma): implications for wild populations. Animal Conservation 11:198-205.

Liu, H. 1998. The change of geographical distribution of two Asian species of rhinoceros in Holocene. Journal of Chinese Geography 8:83-88.

Long, J., M. Archer, T. Flannery and S. Hand 2002. Prehistoric mammals of Australia and New Guinea: one hundred million years of evolution. Sydney: University of New South Wales Press.

Loucks, C.J., Z. Lu, E. Dinerstein, H. Wang, D.M. Olson, C. Zhu and D. Wang 2001. Ecology: Giant pandas in a changing landscape. Science 294:1465.

Louys, J. 2007. Limited effect of the Quaternary's largest super-eruption (Toba) on land mammals from Southeast Asia. Quaternary Science Reviews 26:3108-3117.

Louys, J. 2008. Quaternary extinctions in southeast Asia. In A.M.T. Elewa (ed) Mass extinction, pp159-190 Berlin: Springer.

Louys, J., D. Curnoe and H. Tong 2007. Characteristics of Pleistocene megafauna extinctions in Southeast Asia. Palaeogeography Palaeoclimatology Palaeoecology 243:152-173.

Martin, P.S. and R.G. Klein 1984. Quaternary extinctions: a prehistoric revolution. Tucson: University of Arizona Press.

Medway, L. 1972. The Quaternary mammals of Malesia: a review. In P. S. Ashton and H. M. Ashton (eds) The Quaternary era in Malesia, pp 63-98. Hull: University of Hull.

Mellars, P. 2006. Going east: New genetic and archaeological perspectives on the modern human colonization of Eurasia. Science 313:796-800.

Moore, M. W., T. Sutikna, Jatmiko, M. Morwood and A. Brumm 2009. Continuities in stone flaking technology at Liang Bua, Flores, Indonesia. Journal of Human Evolution 57:503-526.

Morwood, M.J., P.B. O’Sullivan, F. Aziz and A. Raza 1998. Fission-track ages of stone tools and fossils on the east Indonesian island of Flores. Nature 392:173-176.

Myers, J.A., M. Vellend and S. Gardescu 2004. Seed dispersal by white-tailed deer: Implications for long-distance dispersal, invasion and migration of plants in eastern North America. Oecologia 139:35-44.

O'Connor, S. 2007. New evidence from East Timor contributes to our understanding of earliest modern human colonisation east of the Sunda Shelf. Antiquity 81:523-535.

Owen-Smith, R.N. 1988. Megaherbivores: the influence of very large body size on ecology. New York: Cambridge University Press.

Piper, P.J. and E.O. Cranbrook 2007. The potential of large protected plantation areas for the secure re-introduction of Borneo's lost 'megafauna': a case for the Malay tapir Tapirus indicus. In R. Stuebing, J. Unggang, J. Ferner, J. Ferner, B. Giman and K.K. Ping, (eds) Proceedings of the Regional Conference of Biodiversity Conservation in Tropical Planted Forests in Southeast Asia, pp184-191. Kuching: Forest Department.

Piper, P.J., R.J. Rabett and E.O. Cranbrook 2007a. New discoveries of an extinct giant pangolin (Manis cf. palaeojavanica Dubois) at Niah Cave, Sarawak, Borneo: biogeography, palaeoecology and taxonomic relationships. Sarawak Museum Journal 84:207-226.

Piper, P.J., E.O. Cranbrook and R.J. Rabett 2007b. Confirmation of the presence of the tiger Panthera tigris (L.) in late Pleistocene and Holocene Borneo. Malayan Nature Journal 59:257-265.

Piper, P.J., J. Ochoa, H. Lewis, V. Paz and W.P. Ronquillo 2008. The first evidence for the past presence of the tiger Panthera tigris (L.) on the island of Palawan, Philippines: Extinction in an island population. Palaeogeography Palaeoclimatology Palaeoecology 264:123-127. 
Pope, K.O. and J.E. Terrell 2008. Environmental setting of human migrations in the circumPacific region. Journal of Biogeography 35:1-21.

Prasad, S., J. Krishnaswamy, R. Chellam and S.P. Goyal 2006. Ruminant-mediated seed dispersal of an economically valuable tree in indian dry forests. Biotropica 38:679-682.

Pringle, R.M. 2008. Elephants as agents of habitat creation for small vertebrates at the patch scale. Ecology 89:26-33.

Rink, W. J., W. Wei, D. Bekken and H.L. Jones 2008. Geochronology of Ailuropoda-Stegodon fauna and Gigantopithecus in Guangxi Province, southern China. Quaternary Research 69:377-387.

Sartono, S. 1979. The discovery of a pygmy stegodon from Sumba, East Indonesia: an announcement. Modern Quaternary Research in Southeast Asia 5:57-63.

Schepartz, L.A., S. Stoutamire and D.A. Bekken 2005. Stegodon orientalis from Panxian Dadong, a Middle Pleistocene archaeological site in Guizhou, South China: Taphonomy, population structure and evidence for human interactions. Quaternary International 126128:271-282.

Simons, A. and D. Bulbeck 2004. Late Quaternary faunal successions in South Sulawesi, Indonesia. Modern Quaternary Research in Southeast Asia 18:167-190.

Turvey, S.T. 2009a. In the shadow of the megafauna: prehistoric mammal and bird extinctions across the Holocene. In S.T. Turvey (ed.) Holocene extinctions, pp17-39. Oxford: Oxford University Press.

Turvey, S.T. 2009b. Holocene mammal extinctions. In S.T. Turvey (ed.) Holocene extinctions, pp41-61. Oxford: Oxford University Press.

van den Bergh, G., P.Y. Sondaar, J. De Vos and F. Aziz 1996. The proboscideans of the South-East Asian islands. In J. Shoshani and P. Tassy (eds) The Proboscidea: evolution and palaeoecology of elephants and their relatives, pp240-248. Oxford: Oxford University Press.

van den Bergh, G.D., R.D. Awe, M.J. Morwood, T. Sutikna, Jatmiko and E. Wahyu Saptomo 2008. The youngest stegodon remains in Southeast Asia from the Late Pleistocene archaeological site Liang Bua, Flores, Indonesia. Quaternary International 182:16-48.

van den Bergh, G.D., J. de Vos and P.Y. Sondaar 2001. The Late Quaternary palaeogeography of mammal evolution in the Indonesian Archipelago. Palaeogeography Palaeoclimatology Palaeoecology 171:385-408.

Webb, S. 2008. Megafauna demography and late Quaternary climatic change in Australia: A predisposition to extinction. Boreas 37:329-345.

Westaway, K.E., M.J. Morwood, R.G. Roberts, A.D. Rokus, J.X. Zhao, P. Storm, F. Aziz, G. van den Bergh, P. Hadi, Jatmiko and J. de Vos 2007. Age and biostratigraphic significance of the Punung Rainforest Fauna, East Java, Indonesia and implications for Pongo and Homo. Journal of Human Evolution 53:709-717.

Wright, D.D. 2005. Diet, keystone resources and altitudinal movement of dwarf cassowaries in relation to fruiting phenology in a Papua New Guinean rainforest. In J. L. Dew and J. P. Boubli (eds) Tropical fruits and frugivores: the search for strong interactors, pp205-236. Dordrecht: Springer.

Yamashiro, A. and T. Yamashiro 2006. Seed dispersal by kerama deer (Cervus nippon keramae) on Aka Island, the Ryukyu Archipelago, Japan. Biotropica 38:405-413.

Yang, D.Y., L. Liu, X. Chen and C.F. Speller 2008. Wild or domesticated: DNA analysis of ancient water buffalo remains from North China. Journal of Archaeological Science 35:2778-2785.

Zhang, B., M. Li, Z. Zhang, B. Goossens, L. Zhu, S. Zhang, J. Hu, M. W. Bruford and F. Wei 2007. Genetic viability and population history of the giant panda, putting an end to the "Evolutionary dead end"? Molecular Biology and Evolution 24:1801-1810. 